\title{
ÁRVORES DISPERSAS NA PASTAGEM E SUA INFLUÊNCIA SOBRE A REGENERAÇÃO NATURAL DE PLÂNTULAS DE ÁRVORES E ARBUSTOS
}

\author{
Ilmaione Keiza de Souza Oliveira ${ }^{1}$; Rosana Quaresma Maneschy ${ }^{2}$ \\ ${ }^{1}$ Discente do Curso de Agronomia, Faculdade de Ciências Agrárias de Marabá (FCAM), Universidade Federal do Pará \\ (UFPA), Marabá, Pará. Bolsista PARD. E-mail: ilmaionekeiza@ hotmail.com. \\ ${ }^{2}$ Engenheira Agrônoma, Prof. ${ }^{\text {a }}$ D. Sc., FCAM, UFPA. E-mail: romaneschy@ufpa.br.
}

RESUMO: Pesquisas realizadas em diversos países indicam a eficiência do componente arbóreo como incremento na produtividade pecuária. Isto se deve à melhoria do microclima para os animais e plantas, além da ciclagem de nutrientes pelas árvores. As árvores dispersas em pastagens agrícolas proporcionam excelentes habitats e recursos alimentícios para diversos animais. São usadas como local de descanso e alimentação para as aves tanto residentes como migratórias. Além de favorecer a conservação e multiplicação dessas plantas devido à visitação de vários animais que regurgitam e/ou defecam as sementes aumentando a dispersão desde as pastagens degradadas até os campos agrícolas. Com isso, este trabalho objetivou levantar espécies arbóreas dispersas na pastagem e as plântulas arbóreas ou arbustivas invasoras abaixo da copa dessas árvores para comparar a abundância de plântulas e frequiência de estabelecimento destas espécies em pastagens abertas e abaixo das copas das árvores dispersas na pastagem, a serem utilizadas em reflorestamentos de áreas degradas ou na formação de sistemas silvipastoris (SSP). Esse estudo é uma ação do projeto de pesquisa "Regeneração natural de espécies arbóreas na pastagem como alternativa silvipastoril para a sustentabilidade da agricultura familiar no Sudeste do Pará" da Universidade Federal do Pará, Campus Marabá e será realizado no PA Belo Horizonte, situado no km 30 da BR-153 no município de São Domingos do Araguaia no sudeste paraense. O clima local é Am no limite de transição para Aw com temperatura média anual de $26,3^{\circ} \mathrm{C}$, caracterizado por um período menos chuvoso entre os meses de maio e outubro e um período mais chuvoso entre os meses de novembro a abril. Os solos predominantes são latossolo vermelho amarelo distrófico com textura média e podzólico vermelho amarelo com textura argilo-arenosa. Nas propriedades ocorre um predomínio de áreas de pastagens, com ausência de mata e baixa diversificação dos sistemas de produção. Serão selecionados dez piquetes com árvores dispersas na pastagem que tenham pastejo ativo, área média de 0,5 ha e com carga animal semelhante. Serão avaliadas silviculturalmente através da altura total, diâmetro a altura do peito (DAP) e diâmetro de copa (DC) de todas as espécies arbóreas com altura total mínima de 3 metros, dispersas na pastagem. As mesmas terão sua localização geográfica, obtidas através de GPS (Sistema de Posicionamento Global), inseridas em mapas topográficos para a localização das árvores nos piquetes. Serão calculadas as freqüências, absoluta (FA) e relativa (FR) das espécies. Será realizada a avaliação da composição taxonômica e a frequiência de estabelecimento de plântulas de árvores e arbustos abaixo da copa das espécies arbóreas com maior freqüência dispersas na pastagem. Será aplicado uma amostragem pareada, com uma parcela de 2 x $2 \mathrm{~m}\left(4 \mathrm{~m}^{2}\right)$ abaixo da copa de cada árvore identificada e uma parcela controle de tamanho igual situada em pastagem aberta. Para a avaliação da similaridade entre as populações botânicas será utilizado o Índice de Similaridade de Sorense. Espera-se levantar as espécies de regeneração natural, úteis ao reflorestamento de áreas de pastagens degradadas e formação de sistemas silvipastoris, buscando a sustentabilidade para a agricultura familiar no sudeste do Pará.

PALAVRAS - CHAVE: Micro sítios para germinação, pastagem, restauração, sistema silvipastoril. 